\title{
Optimization of a methodology for simultaneous determination of four antidepressants present in fresh water by high efficiency liquid chromatography
}

\author{
Otimização de metodologia para determinação simultânea de quatro \\ antidepressivos presentes em água doce por cromatografia líquida de alta \\ eficiência
}

\author{
Patrícia Alexandre Evangelista' \\ Franz Zirena Vilca" \\ Rodrigo Floriano Pimpinato'II \\ Valdemar Luiz Tornisielo ${ }^{\mathrm{IV}}$
}

\begin{abstract}
The occurrence of emerging contaminants is a growing concern in the environmental scenario due to their potential risks to ecosystems. The technologies employed in the treatment of sewage in Brazil are not efficient in removing micropollutants, especially persistent ones. Antidepressants (a class of drugs belonging to emerging contaminants) can reach the environment through the disposal of domestic and industrial effluents. These substances were detected in studies with surface waters, being able to cause changes and accumulate in aquatic organisms. The occurrence and impacts of this class of pollutant are still poorly studied in the country. Thus, there is a need to carry out environmental monitoring. To meet such a goal, scientific advances must be developed, especially those related to the development of analytical skills, equipment, and methods with the necessary sensitivity to research in the different sources of contamination. Accordingly, with the development of analytical techniques, it is possible to determine antidepressant drugs in environmental and / or biological matrices in increasingly small concentrations. Consequently, optimization of current techniques and proposing new ones are crucial before any other actions. The aim of this study was to validate a rapid methodology for determining the presence of four antidepressants - fluoxetine, citalopram, venlafaxine, and sertraline - in fresh water through high performance liquid chromatography. The method involved solid-phase extraction (SPE) with C18 cartridge and quantification by high performance liquid chromatography coupled to a diode array detector with C8 column. No chromatographic interference was observed in the retention time of the antidepressants in this study at the selected wavelength of $235 \mathrm{~nm}$. The study matrix did not interfere in the analyses. Linearity was adequate for the range from 0.5 to $10 \mu \mathrm{g} \mathrm{mL}^{-1}$, with limits of detection and quantification of 0.03 to $0.09 \mathrm{\mu g} \mathrm{mL}^{-1}$ and 0.10 to $0.27 \mathrm{\mu g} \mathrm{mL}^{-1}$ respectively. Accuracy was assessed by testing sample fortification at three concentration levels and estimated by relative standard deviation (RSD). RSD values below $15 \%$ were obtained. The recovery interval ranged from 49 to $102 \%$. The analytical method was validated and considered satisfactory for the simultaneous determination of antidepressants in freshwater samples using a C8 column.
\end{abstract}

Keywords: Emerging pollutants; Analytical validation; Monitoring.

\footnotetext{
'University of São Paulo, São Paulo, SP, Brazil - patriciaaevangelista@usp.br.

"National University of Moquegua, Moquegua, Peru - fzirenav@unam.edu.pe.

III University of São Paulo, São Paulo, SP, Brazil - ropimpinato@cena.usp.br.

Iv University of São Paulo, São Paulo, SP, Brazil - vltornis@cena.usp.br.
} 


\section{Resumo}

A ocorrência de contaminantes emergentes é uma preocupação crescente no cenário ambiental, tendo em vista os riscos em potenciais sobre os ecossistemas. As tecnologias empregadas no tratamento de esgotos no Brasil não são eficientes na remoção de micropoluentes, em especial os persistentes. Os antidepressivos (uma classe de fármacos pertencentes aos contaminantes emergentes) podem chegar ao meio ambiente por meio do descarte de efluentes domésticos e industriais. Essas substâncias foram detectadas em estudos com águas superficiais, sendo capazes de provocar alterações e se acumularem em organismos aquáticos. A ocorrência e os impactos dessa classe de poluente ainda são pouco estudados no país. Há uma necessidade de realizar o monitoramento ambiental. Para tal, avanços científicos devem ser elaborados, especialmente aqueles ligados ao desenvolvimento de competências analíticas, equipamentos e métodos com a sensibilidade necessária à investigação nos diferentes focos de contaminação. Assim, com a elaboração de técnicas analíticas é viável a determinação fármacos antidepressivos em matrizes ambientais e/ou biológicas em concentrações cada vez menores. Dessa forma, a otimização e a proposição de novas técnicas são fundamentais antes de quaisquer outras ações. O objetivo deste estudo foi efetuar uma validação de metodologia rápida para determinação de quatro antidepressivos - fluoxetina, citalopram, venlafaxina e sertralina - em água doce utilizando cromatografia líquida de alta eficiência. Foi utilizado o método de extração em fase sólida (SPE) com cartucho C18 e cromatografia líquida acoplada detector arranjo de diodos com coluna C8. Não foi observada interferência cromatográfica no tempo de retenção dos antidepressivos deste estudo no comprimento de onda selecionado de $235 \mathrm{~nm}$. A matriz do estudo não interferiu nas análises. A linearidade foi adequada para a faixa de 0,5 a $10 \mu \mathrm{g} \mathrm{mL}^{-1}$, com limites de detecção e quantificação de 0,03 a $0,09 \mu \mathrm{g} \mathrm{mL}^{-1}$ e de 0,10 a $0,27 \mu \mathrm{g} \mathrm{mL}^{-1}$, respectivamente. A precisão foi avaliada testando a fortificação das amostras em três níveis de concentração, e estimada pelo desvio padrão relativo (DPR), foi obtido valores de DPR abaixo de $15 \%$. O intervalo de recuperação variou de 49 a 102\%. O método analítico foi validado e considerado satisfatório para a determinação simultânea de antidepressivos em amostras de água doce utilizando uma coluna C8.

Palavras-Chave: Poluentes emergentes; Validação analítica; Monitoramento.

\section{Introduction}

Population growth results in a high demand for services and products, which results in an increase in processes for the development of new compounds. Within this context, pharmaceutically active compounds (PhACs) stand out, which are excreted via urine and feces as active unchanged substances, metabolites, or even in the form of glucuronic acid due to incomplete removal in sewage treatment plants ( STPs) leading to contamination of environmental compartments (BARCELÓ, 2007; COLAÇO et al., 2015).

The use of PhACs is growing in terms of spending and consumption especially antidepressants. This is due to the discovery of new drugs, the expanding population, the inverse age structure of the general population, as well as the expiration of patents resulting in less expensive generics availability (OECD, 2013; COSTA JUNIOR et al., 2014). 
Antidepressants act on the different neurotransmitters involved in mood regulation. These compounds are subdivided based on their chemical structure and / or mechanism of action. Classes of antidepressants include selective serotonin reuptake inhibitors, tricyclic antidepressants, monoamine oxidase inhibitors, serotonin and norepinephrine uptake inhibitors, selective noradrenaline reuptake inhibitors, serotonin reuptake inhibitors and antagonists, noradrenergic and serotonin-specific antidepressants, dopamine reuptake inhibitors, and antidepressants with direct effect on neuroreceptors (WILLE et al., 2008).

Antidepressants can reach the environment through wastewater as a result of disposal of domestic effluents and hospital and industrial sources (MONTEIRO and BOXALL, 2010). The technologies used in the treatment of sewage in Brazil are the anaerobic reactors or the association of aerobic and anaerobic reactors. These have a lower energy and operating consumption, generating a smaller amount of sludge when compared to the conventional activated sludge system. However, these processes are not able to remove micropollutants entirely.

Therefore, the presence of pharmaceutical products at trace levels (ng $\mathrm{L}^{-1}$ and $\mu \mathrm{g} \mathrm{L}^{-}$ $\left.{ }^{1}\right)$ has been reported in wastewater, surface and groundwater and, to a lesser extent, drinking water (GROS et al., 2012; LOLIC et al., 2015; CAI et al., 2015; SANTOS et al., 2013; PEREIRA et al., 2016). In addition, the lack of basic sanitation causes pollution of water resources where natural wastewater is discharged into bodies of water. In this way, drugs excreted in the urine and feces or discarded through sink and toilets come into contact with the environment (VON SPERLING, 2005).

Studies on the degradation or effective treatment of residual drugs are still scarce including antidepressants and their metabolites. Some research shows only the removal of pollutants, which is the transfer of pollutants to sludge and sediments (VERLICCHI et al., 2012; SIM et al., 2010). The decomposition or removal of antidepressants during water treatments does not necessarily mean the removal of their toxicity since a large number of transformation products can be formed, being more stable in the environment and exerting greater toxicity for non-target organisms than its original compounds (MA et al., 2020). 
Even though the concentrations of this type of drugs and their metabolites generally found in surface waters are considered to be low concentrations, their potential effects on fauna, flora, and human health especially with prolonged exposure must be considered and studied particularly in vulnerable populations (COELHO et al., 2019). Pharmaceutical products modify the regulation of neurotransmitters and disrupt homeostasis throughout the central and peripheral nervous system both in vertebrates and invertebrates. In fact, psychiatric drugs are one of the most toxic drugs for aquatic organisms (GIEBUŁTOWICZ and NAŁĘCZ-JAWECKI, 2014).

Therefore, there is a need to carry out environmental monitoring. To this end, scientific advances must be developed, especially those related to the development of analytical skills, equipment, and methods with the necessary sensitivity to research in the different sources of contamination. Thus, with the development of analytical techniques, it is feasible to determine antidepressant drugs in environmental and / or biological matrices in increasingly small concentrations. So, optimization and the development of new techniques are essential before any other actions (COSTA JUNIOR et al., 2014). The creation of analytical methodologies for simultaneous analysis of trace levels of human pharmaceutical products in a wide range of aquatic environmental matrices is useful and necessary in order to make it possible to gather data on different forms of entry of these compounds into the environment and, at the same time, assess the impact and distribution of medicines for human use in the aquatic environment (PAÍGA et al., 2017).

Taking all of these aspects into consideration, the objective of this study was to validate a rapid methodology for determining four antidepressants - fluoxetine, citalopram, venlafaxine and sertraline - in fresh water using high-performance liquid chromatography coupled to UV detector by diode array.

\section{Material e Methods}

\subsection{Reagents and materials}


The antidepressants venlafaxine (VEN), citalopram (CIT), fluoxetine (FLU), and sertraline (SER) were obtained in the form of reference standards for handling pharmacies with $99.98 \%$ purity (Rosário ${ }^{\circledR}$, São Carlos, SP, Brazil).

The water samples used to optimize the method were obtained from a spring in Piracicaba city (latitude $22^{\circ} 47^{\prime} 34,13^{\prime \prime} \mathrm{S}$ and longitude $47^{\circ} 45^{\prime} 12,01^{\prime \prime} \mathrm{O}$ ).

The solvents used in the extraction and elution were acetonitrile (ACN) (MTedia, USA), methanol (MeOH) (MTedia, USA), with high performance liquid chromatography (HPLC), ultrapure water (Pura-Q, Brazil) and ammonium acetate (Sigma-Aldrich, USA). A 0.2 $\mu \mathrm{m}$ polytetrafluoroethylene membrane filter (Advantec, Japan) was used to filter the samples.

Chromatographic analyzes were performed on an Agilent model 1200 liquid chromatography equipment coupled to a diode array detector (DAD) (Agilent Technologies, Palo Alto, USA). Data processing and control of the HPLC modules was performed using ChemStation software.

\subsection{Extraction protocol}

In the solid phase extraction (SPE) procedure, a peristaltic pump (Ismatec IPC, SWI) was used which provided constant flow during the experiment. A C18 cartridge (500 mg, 6 $\mathrm{mL}$ ) from Waters Corporation was used with an adequacy of $5 \mathrm{~mL} \mathrm{MeOH}$ and $5 \mathrm{~mL}$ ultrapure $\mathrm{H} 2 \mathrm{O}$. Then, the $1 \mathrm{~L}$ samples (collected in a spring), previously filtered through a $0.2 \mu \mathrm{m}$ membrane filter were passed through the cartridge to concentrate the analytes of interest. The flow used was $5 \mathrm{~mL} \mathrm{~min}{ }^{-1}$ constant of sample. Vacuum drying for approximately 20 minutes in a multiple vacuum system (Vacuubrand, DEU) was employed. The washing was performed with $2 \times 5 \mathrm{~mL}$ of MeOH (REIS et al., 2019). The extracts were collected, dried in nitrogen, and re-suspended in $\mathrm{ACN}$ and $0.05 \mathrm{M}$ ammonium acetate in the proportions of $40 \%$ and $60 \%$ respectively.

\subsection{Chromatographic conditions}


The stock solutions of the analytes were prepared in $\mathrm{MeOH}$ at a concentration of $1000 \mu \mathrm{g} \mathrm{mL} \mathrm{L}^{-1}$, kept at $-20^{\circ} \mathrm{C}$, and renewed every 3 months. The working solution was prepared from the stock solutions, in ultrapure water containing all antidepressants in appropriate amounts of each solution at a concentration of $100 \mu \mathrm{g} \mathrm{mL}^{-1}$ for fortifications.

The analytes were separated on a Zorbax Elipse Plus C8 column $(2.1 \mathrm{~mm}$ x $150 \mathrm{~mm}$; $3.5 \mu \mathrm{m}$ ) at a temperature of $25^{\circ} \mathrm{C}$ with an injection of $20 \mu \mathrm{L}$. Elution was performed using a linear gradient of the mobile phase starting with 40\% ACN and 60\% $0.05 \mathrm{M}$ ammonium acetate, which changed to 50:50 ( $\mathrm{v} / \mathrm{v})$ in 2 minutes, returning to the initial condition of 40 : $60(\mathrm{v} / \mathrm{v})$ in 5 minutes and remained in this condition for another 7 minutes, totaling a running time of 15 minutes.

The flow rate was $0.5 \mathrm{~mL} \mathrm{~min}^{-1}$ with a pressure of 243 bar. Peak identification was performed using retention times and spectral information provided by the DAD at $235 \mathrm{~nm}$.

\subsection{Matrix effect}

To evaluate the matrix effect under the sensitivity of the analytical method, extracts were obtained from water samples collected in a spring. The calibration curve was prepared at concentrations of $0.5 \mu \mathrm{g} \mathrm{mL}^{-1} ; 1.0 \mu \mathrm{g} \mathrm{mL}^{-1} ; 2.5 \mu \mathrm{g} \mathrm{mL}^{-1} ; 5 \mathrm{gg} \mathrm{mL}^{-1}$, and $10 \mu \mathrm{g} \mathrm{mL}^{-1}$, each point in triplicate, using the matrix extract solution to dissolve the analytical standards at each concentration level, while another calibration curve was made using the mobile phase (40\% ACN and 60\% $0.05 \mathrm{M}$ ammonium acetate). To compare the slope coefficients, the ratio between the slope of the matrix and the solvent was performed, as well as the application of a t test to compare the averages at the $95 \%$ significance level.

\subsection{Validation}

The parameters of the analytical validation were performed according to the National Health Surveillance Agency (ANVISA, 2017). Selectivity was assessed by comparing retention times and UV spectra of analytes in standard solutions and samples. Linearity was verified using 5 (five) different concentrations of $0.5 ; 1.0 ; 2.5 ; 5.0$; and $10 \mu \mathrm{gL} \mathrm{m}^{-1}$ in triplicate prepared independently and diluted from the working solution. 
The linearity criteria for accepting the curve were the correlation coefficients and the line equation $(y=a x+b)$. For the evaluation of linearity, regression analysis with analysis of variance (ANOVA) was applied at the 95\% confidence level using Minitab 19.2020.1 statistical software. The absence of outliers was demonstrated at each concentration level by the Grubbs test (MILLER \&; MILLER, 2010).

The accuracy of the method was assessed at repeatability levels with the samples under the same operating conditions - same analyst, instrumentation, and a single analytical run. Three concentrations were used that contemplate the linear range of the analytical method $1.0 \mu \mathrm{g} \mathrm{mL}^{-1}$ (low), $2.5 \mathrm{\mu g} \mathrm{mL}^{-1}$ (average), and $5.0 \mu \mathrm{g}$ $\mathrm{mL}^{-1}$ (high), with five replicates in each level. In addition to the repeatability, the intermediate precision was analyzed on two different days for the concentration of $5 \mathrm{\mu g} \mathrm{mL}^{-}$ ${ }^{1}$ with five repetitions. The analysis was demonstrated by the dispersion of the results calculating the relative standard deviation (RSD) of the series of measurements according to Equation (1).

$$
R S D=\frac{S D}{\bar{x}} \cdot 100
$$

Where SD is the standard deviation and $\bar{x}$ the mean concentration determined.

The accuracy was verified from three concentrations that contemplate the linear range of the analytical method $1.0 \mu \mathrm{g} \mathrm{mL}^{-1}$ (low), $2.5 \mu \mathrm{g} \mathrm{mL}^{-1}$ (average), and $5.0 \mu \mathrm{g}$ $\mathrm{mL}^{-1}$ (high), with five replicas on each level. The samples were prepared independently and diluted from the same stock solution. The recovery was calculated according to Equation (2).

$$
\text { Recovery }=\frac{E C_{(\text {added sample })}-E C_{(\text {sample })}}{T C A}
$$

Where EC is the experimental concentration of the analyte and TCA is the theoretical concentration of the added analyte.

The limits of detection (LD) and quantification (LQ) were determined from Equations (3) and (4) using data from the calibration curves. 


$$
\begin{aligned}
& L D=\frac{3,3 \sigma}{b} \\
& L Q=\frac{10 \sigma}{b}
\end{aligned}
$$

\section{Results and discussion}

\subsection{Matrix effect}

Water is considered a simple matrix, but interfering with humic and fulvic acids can result in matrix effects. In the analysis of drugs, the matrix effect has been shown to be an adversity that must be considered for each type of substance, as well as for each type of matrix analyzed. This factor occurs due to the variability of physical-chemical properties and the complexity of the matrices.

Thus, the extraction procedure is an essential tool for cleaning the sample in order to obtain the elimination or compensation of the matrix effect (HALL et al., 2012; PENG et al., 2008). Figure 1 shows the curves obtained between matrix and solvent. Table 1 shows the data obtained regarding the matrix effect.

Figure 1 - Calibration curve between matrix (water) and solvent for VEN, CIT, FLU, and SER 


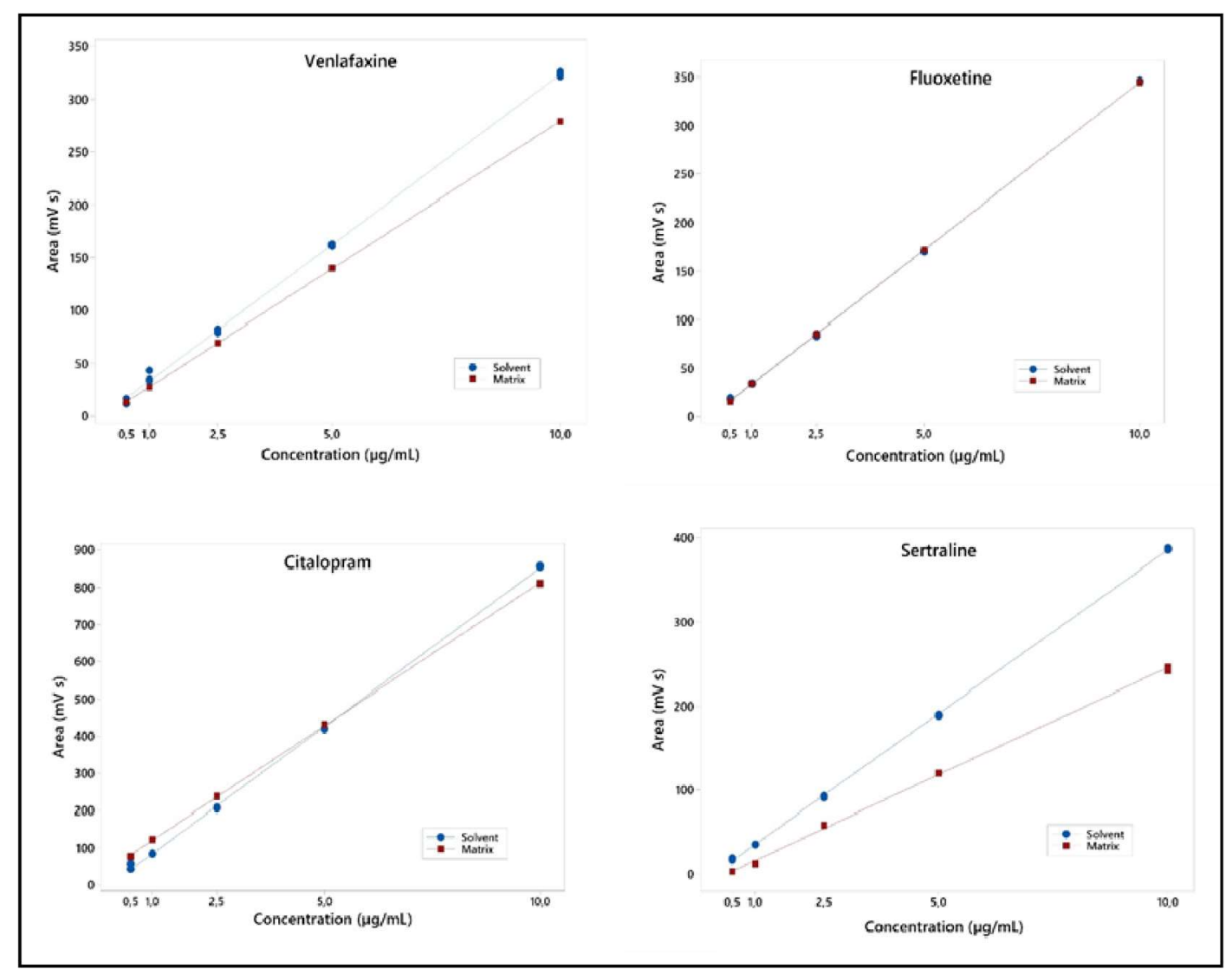

Table 1 - Calibration characteristics of the matrix effect

\begin{tabular}{|c|c|c|c|c|c|c|}
\hline \multirow{3}{*}{ Antidepresssants } & \multicolumn{4}{|c|}{ Calibration data } & \multirow{3}{*}{ S/w Relation } & \multirow{3}{*}{$t$-Test } \\
\hline & \multicolumn{2}{|c|}{$\mathbf{R}^{2}$} & \multicolumn{2}{|c|}{ Angular coefficients } & & \\
\hline & Solvent & Water & Solvent & Water & & \\
\hline VEN & 0,9995 & 1 & 45,55 & 27,98 & 0,61 & 1,41 \\
\hline CIT & 0,9994 & 0,9998 & 121,62 & 77,09 & 0,63 & 0,93 \\
\hline FLU & 0,9993 & 1 & 49,88 & 34,58 & 0,69 & 1,02 \\
\hline SER & 0,9989 & 0,992 & 56,64 & 25,53 & 0,45 & $-2,06$ \\
\hline
\end{tabular}

The correlation coefficients of all curves for both the solvent and the matrix were above 0.990 . When the ratio between the slope of the matrix and the solvent is greater than 1.0, the matrix effect is positive, while a value below 1.0 indicates a negative matrix effect (PINHO et al., 2010). The ratio between the matrix and solvent slopes was below 1.

At the $95 \%$ significance level and degrees of freedom equal to 29 , the value of $t$ corresponds to $t$ critical $(0.05 ; 29)=2.045$. The comparisons were considered statistically equal, since the calculated $t$ values were lower than the $t$ critical, so there is no interference from the matrix in the study. 


\subsection{Validation}

The analytical methodology developed was validated taking into account the following criteria: linearity, sensitivity (in terms of detection of methods and limits of quantification), recoveries, precision, and matrix effects. The retention times (RT) for the analytes were VEN 1.351; CIT 1,979; FLU 3,416; and SER 4,123.

No chromatographic interference was observed in the RT of the antidepressants in this study at the selected wavelength of $235 \mathrm{~nm}$. Additionally, the chromatograms obtained did not show a peak in the region of determination of the analytes demonstrating that the method showed high selectivity. In Figure 2, the chromatogram resulting from the concentration of $10 \mathrm{\mu g} \mathrm{mL}^{-1}$ is visualized.

The linearity of the method was established for each compound and evaluated by independent analytical curves prepared in the solvent and in the matrix. For the tests, curves were prepared at five levels $\left(0.5 ; 1.0 ; 2.5 ; 5.0\right.$ and $\left.10 \mu \mathrm{gL}^{-1}\right)$ with three independent repetitions per level and a $95 \%$ confidence limit. The parameters for calibration and linearity analysis are shown in Table 2. 
Figure 2 - Chromatogram of the separation of antidepressants VEN min 1.351 ; CIT min 1,979; FLU min 3.416; and SER min 4.123 at a concentration of $10 \mu \mathrm{g} \mathrm{mL}^{-1}$

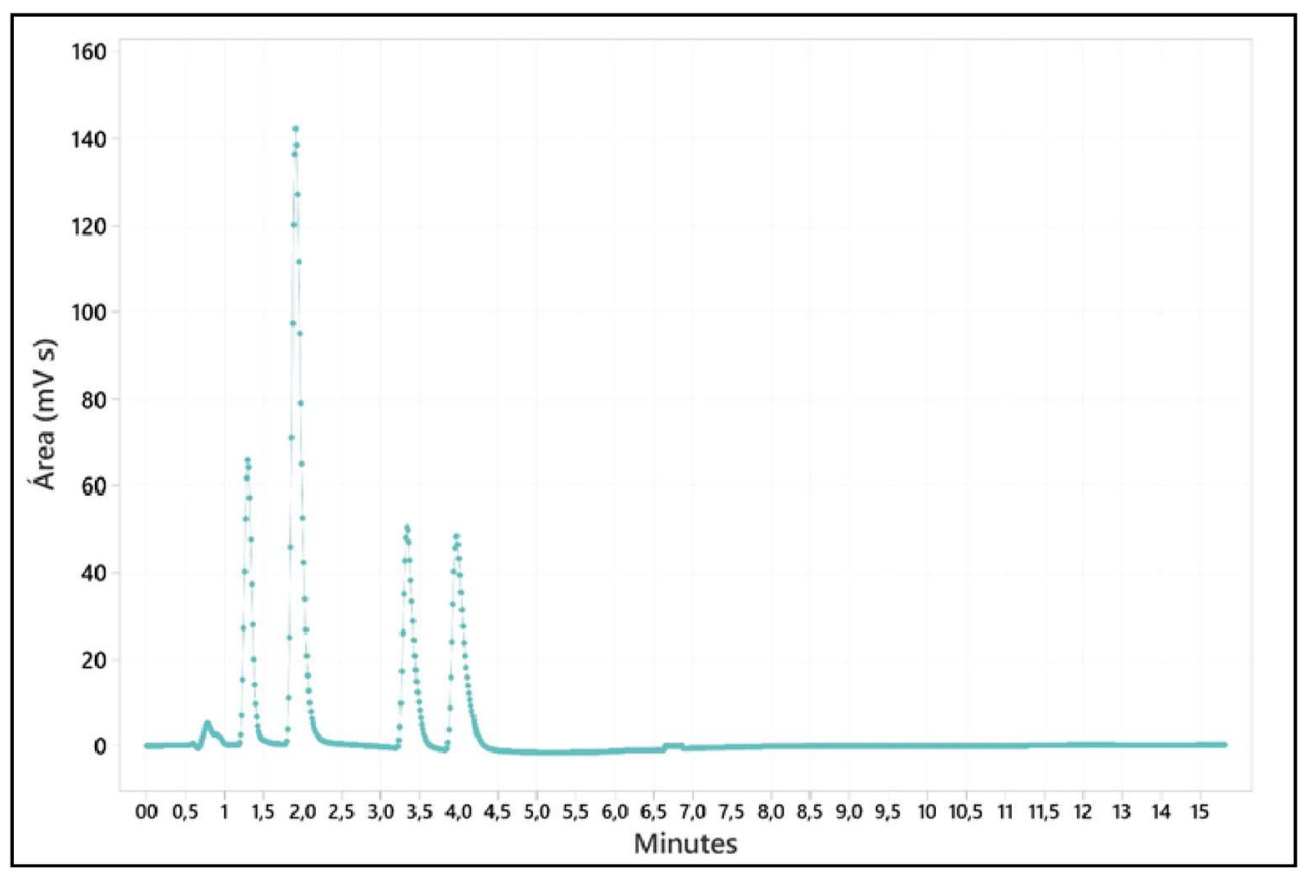

Table 2 - Analysis of the linearity of the validation of the analytical method for antidepressants

\begin{tabular}{lllllll}
\hline & & \multicolumn{2}{c}{ Regression } & & \multicolumn{2}{c}{ Lack of adjustment } \\
& \multicolumn{1}{c}{ Equation } & $\mathbf{R}^{\mathbf{2}}$ & $\mathbf{F}_{\text {calculated }}$ & $\mathbf{p}$-Value & $\mathbf{F}_{\text {calculated }}$ & p-Value \\
\hline VEN & $y=45,55 x+2,670$ & 0,9995 & 28165,96 & 0 & 1,14 & 0 \\
CIT & $y=121,6 x-2,334$ & 0,9994 & 23091,89 & 0 & 0,99 & 0 \\
FLU & $y=49,88 x-1,332$ & 0,9993 & 19386,07 & 0 & 1,26 & 0 \\
SER & $y=56,79 x-5,2888$ & 0,9988 & 10502,06 & 0 & 2,55 & 0 \\
\hline
\end{tabular}

Critical F of the regression $(0.05 ; 1 ; 13)=4.67$; Critical F for lack of adjustment $(0.05 ; 3 ; 10)=3.71$.

The equations were obtained using the least squares method and presented excellent determination coefficients $\left(R^{2} \geq 0.99\right)$, indicating good adherence to the linear model for all substances studied (ANVISA, 2017). The F values calculated by ANOVA were higher than the critical value for all antidepressants, both in the high and low ranges, indicating that the regressions are statistically valid. The $\mathrm{F}$ values, obtained for the lack of adjustment test were lower than the critical value, showing that the linear model describes 
the correlations between the peak areas and the concentrations in the ranges properly evaluated. The $p$-values were less than 0.05 , so the regressions were considered satisfactory.

The detection limits and the quantification limits for methods ranged from 0.03 to $0.09 \mu \mathrm{g} \mathrm{mL}^{-1}$ and from 0.10 to $0.27 \mathrm{gg} \mathrm{mL}^{-1}$ respectively (Table 3). These values show that the analytical method developed has a good sensitivity.

The precision of a method is the proximity of the agreement between independent test results obtained under stipulated conditions. Accuracy is generally expressed in terms of RSD. The RSD in this study can be seen in Tables 3 and 4. The values for repeatability ranged from $3.78 \%$ to $7.30 \%$ for VEN; $5.01 \%$ to $11.1 \%$ for CIT; $9.60 \%$ to $14.63 \%$ for FLU; and $7.6 \%$ to $12.27 \%$ for SER. The intermediate precision for the concentration of $5.0 \mu \mathrm{g} \mathrm{mL}^{-1}$ was between 5.03 to $7.87 \%$.

All RSD values were below $15 \%$ for all substances, indicating a good precision of the method (AOAC, 2016; ANVISA, 2003) considering the tested fortification levels. The imprecision of a method increases as the concentration of the analyte decreases (AOAC, 2016). This fact can be observed in the values obtained from RSD in this study, in which in the lowest concentrations the values were higher. Accuracy was assessed through recovery experiments and the experiments were carried out using three concentrations $(1,0 ; 2.5$ and $5.0 \mu \mathrm{g} \mathrm{L}^{-1}$ ) low, medium, and high, with five repetitions covering the linear ranges of this study. The recovery values can be seen in Table 4.

The recovery values obtained at the three levels evaluated ranged from 71.13 to 94.73\% for VEN; 74.7 to $109.8 \%$ for CIT; 72.35 to $79.23 \%$ for FLU; and 49.56 to $64.1 \%$ for SER. Percentages of recovery close to $100 \%$ are desirable, however, lower values are admitted, provided that the recovery is precise and exact. In this study, the precision and accuracy of the method was proven, and the recoveries obtained are acceptable (ANVISA, 2003). Furthermore, no test was performed to assess the retention of analytes in the filtration membrane.

The robustness of the method was evaluated by variations in the chromatographic conditions used. Decreasing the temperature and changing the flow by $10 \%$ did not change 
the retention times of the substances, in addition to not generating significant variations in the areas obtained. The RSD values found ranged from 2.7 to $5.4 \%$.

In a study of drugs including fluoxetine using C18 cartridge for solid phase extraction, recoveries below $50 \%$ were obtained (REIS et al.; 2019). Fluoxetine was analyzed with other drugs in estuarine waters and recoveries of 48.7 to $59.7 \%$ were obtained (MADUREIRA et al., 2010). Recoveries in the range of $80 \%$ to $110 \%$ have been obtained for some pharmaceutical products in mineral waters in France (DÉVIER et al. 2013).

Table 3 - Limit values of detection and quantification, intermediate precision, and repeatability of the validation of the analytical method for antidepressants

\begin{tabular}{lcccc}
\hline & \multicolumn{2}{c}{ Limits } & \multicolumn{2}{c}{ Precision } \\
\cline { 2 - 5 } Antidepressants & LD $\mathbf{~ g ~ ~ \mathbf { ~ L } ^ { - 1 }}$ & LQ $\mathbf{~ g ~ m L ~}^{-1}$ & Repeatability \% & Intermediate \% \\
\hline VEN & 0,09 & 0,27 & 3,95 & 5,24 \\
CIT & 0,04 & 0,11 & 8,01 & 5,03 \\
FLU & 0,03 & 0,10 & 9,6 & 5,05 \\
SER & 0,08 & 0,23 & 7,62 & 7,87 \\
\hline
\end{tabular}

Table 4 - Analysis of repeatability and recovery of validation of the analytical methods for antidepressants

\begin{tabular}{|c|c|c|c|c|}
\hline Antidepressants & $\begin{array}{c}\text { Concentration level } \\
\mu \mathrm{g} \mathrm{m \textrm {mL } ^ { - 1 }}\end{array}$ & $\begin{array}{c}\text { Average } \mathrm{n}=5 \\
\mathrm{\mu g} \mathrm{mL}^{-1}\end{array}$ & Recovery \% & RSD \% \\
\hline & 1 & 0,711 & 71,13 & 7,3 \\
\hline \multirow[t]{3}{*}{ VEN } & 2,5 & 1,856 & 74,30 & 3,78 \\
\hline & 5 & 4,710 & 94,42 & 3,95 \\
\hline & 1 & 0,747 & 74,7 & 11,1 \\
\hline \multirow[t]{3}{*}{ CIT } & 2,5 & 2,560 & 102,40 & 5,01 \\
\hline & 5 & 5,49 & 109,8 & 8,01 \\
\hline & 1 & 0,749 & 74,91 & 14,63 \\
\hline \multirow[t]{3}{*}{ FLU } & 2,5 & 1,808 & 72,35 & 7,22 \\
\hline & 5 & 3,961 & 79,23 & 9,6 \\
\hline & 1 & 0,605 & 60,51 & 12,23 \\
\hline \multirow[t]{2}{*}{ SER } & 2,5 & 1,239 & 49,56 & 12,27 \\
\hline & 5 & 3,203 & 64,07 & 7,62 \\
\hline
\end{tabular}

Venlafaxine, fluoxetine, citalopram, and sertraline were determined together with ten other drugs in a study in Germany, with recoveries of $86 \%$ for CIT, $85 \%$ for FLU and SER, and 
$87 \%$ for VEN. The methods used were solid phase extraction and LC-MS analysis (SCHLÜSENER et al. 2015).

In a study carried out in Greece using sewage treatment plant sludge employing LCMS / MS analysis in the determination of 148 drugs and illicit drugs, recoveries of $73 \%$ were obtained for citalopram, $19 \%$ for fluoxetine, $36 \%$ for sertraline, and $89 \%$ for venlafaxine (GAGO -FERRERO et al., 2015).

Thus, recoveries reported in the literature are similar to the values reported in this study. It is worth mentioning that low recoveries are recurrent when multi-residue analyzes are applied. This factor is related to the differences in the physical-chemical properties of these compounds and the extraction conditions used that do not allow higher recoveries for all analytes (FERNANDES et al., 2020).

The validations for simultaneous determination of antidepressants are performed in chromatographic columns, mostly C18 (REIS et al.; 2019; LIOUPI et al.; 2019; PAIGA et al.; 2017). This study demonstrates the possibility of using a C8 column. The presentation of quick and less costly methods is a decisive factor in making environmental monitoring viable. However, good results were obtained in the validation of the analytical method for determining four antidepressants in fresh water using high efficiency chromatography and solid-phase extraction.

\section{Conclusion}

The protection of the aquatic ecosystem from the pollution of pharmaceutical products is of utmost importance and its impact on the environment must be assessed. A sensitive analytical method based on SPE followed by LC-DAD analysis was developed and optimized for simultaneous analysis of four antidepressants including venlafaxine, citalopram, fluoxetine, and sertraline in fresh surface water.

The validation was carried out according to the criteria of a regulatory body. The method showed high selectivity - the chromatograms did not show a peak in the region of determination of the analytes - good adherence to the linear model, high precision, good 
recovery, and the limits of detection and quantification demonstrated that the method is sensitive.

The use of a C8 column to separate the analytes proved to be efficient and a good alternative for analysis. Thus, it is considered that the method is satisfactory, as it has proved to be an adequate, efficient, simple, economical and fast tool, in addition to being in accordance with other current research found in the literature.

However, it is hoped that this study can serve as a guiding basis for the analysis of antidepressants in aquatic freshwater environments, acting as an important tool along with environmental monitoring programs.

\section{Acknowledgements}

The authors wish to acknowledge the financial support from the National Council for Scientific and Technological Development (CNPq).

\section{Bibliographic references}

ANVISA. Agência Nacional de Vigilância Sanitária. Resolução da diretoria colegiada n.166, de 24 de julho de 2017. Dispõe sobre a validação de métodos analíticos e dá outras providências.

ANVISA. Agência Nacional de Vigilância Sanitária. Resolução RE nº 899, de 29 de maio de 2003. Guia para Validação de Métodos Analíticos e Bioanalíticos.

AOAC. Association of Official Analytical Chemists. Official methods of analysis of AOAC International. Appendix F: Guidelines for Standard Method Performance Requirements. 2016. p. 1-16

BARCELÓ, D. Pharmaceutical-residue analysis. Trends in Analytical Chemistry. 2007;2(6):454455.

CAI, M. Q.; WANG, R.; FENG, L.; ZHANG, L. Q. Determination of selected pharmaceuticals in tap water and drinking water treatment plant by high-performance liquid chromatographytriple quadrupole mass spectrometer in Beijing, China Environmental Science Pollution Research 2015;22:1854-1867. 
COELHO, M. M.; RIBEIRO, A. R. L.; SOUSA, J. C. G.; RIBEIRO, C.; FERNANDES, C.; SILVA, A. M. T.; et al. Dual enantioselective LC-MS/MS method to analyse chiral drugs in surface water: Monitoring in Douro River estuary. Journal of Pharmaceutical and Biomedical Analysis. 2019;170(5):89-101.

COLAÇO, R.; GOMES, E. C.; PERALTA-ZAMORA, P. G. Poluição por resíduos contendo compostos farmaceuticamente ativos: aspectos ambientais, geração a partir dos esgotos domésticos e a situação do Brasil. Revista de Ciências Farmacêuticas Básica e Aplicada. 2015;35(4): 539-548.

COSTA JUNIOR, I. L.; PLETSCH, A. L.; TORRES, Y. R. Ocorrência de fármacos antidepressivos no meio ambiente- revisão. Revista Virtual de Química. 2014;6(5):1408-1431.

FERNANDES, M. J.; PAIGA, P.; SILVA, A.; LLAGUNO, C. P.; CARVALHO, M.; VÁZQUEZ, F. M.; DELERUE-MATOS, C. Antibiotics and antidepressants occurrence in surface waters and sediments collected in the north of Portugal. Chemosphere. 2020;239:124729.

GAGO-FERRERO, P.; BOROVA, V.; DASENAKI, M. E.; TAUHOMAIDIS, NU S. Simultaneous determination of 148 pharmaceuticals and illicit drugs in sewage sludge based on ultrasound-assisted extraction and liquid chromatography-tandem mass spectrometry. Analytical and bioanalytical chemistry. 2015; 407: 4287-4297.

GIEBUŁTOWICZ, J.; NAŁĘCZ-JAWECKI, G. Occurrence of antidepressant residues in the sewage-impacted Vistula and Utrata rivers and in tap water in Warsaw (Poland). Ecotoxicology and Environmental Safety. 2014;104:103-109.

GROS, M.; MOZAZ, R.; BARCELÓ, D. Fast and comprehensive multi-residue analysis of a broad range of human and veterinary pharmaceuticals and some of their metabolites in surface and treated waters by ultra-high-performance liquid chromatography coupled to quadrupole-linear ion trap tandem mass spectrometry J. Journal of Chromatography A. 2012;1248:104-121.

HALL, T.; SMUKSTE, I.; BRESCIANO, K. R.; WANG, Y.; MCKEARN, D.; SAVAGE, R. E. Identifying and Overcoming Matrix Effects in Drug Discovery and Development. Tandem Mass Spectrometry - Applications and Principles. Jeevan K. Prasain, IntechOpen. 2012, p. 389-420.

LIOUPI, A.; KABIR, A.; FURTON, K. G.; SAMANIDOU, V. Fabric phase sorptive extraction for the isolation of five common antidepressants from human urine prior to HPLC-DAD analysis. Journal of Chromatography B. 2019;1118:171-179.

LOLIC, A.; PAIGA, P.; SANTOS, L. H. M. L. M.; RAMOS, S.; CORREIA, M.; DELERUE-MATOS, C. Assessment of non-steroidal anti-inflammatory and analgesic pharmaceuticals in seawaters of North of Portugal: Occurrence and environmental risk Sci. Total Environ. 2015;508:240250. 
REIS, E. O.; FOUREAUX, A. F. S.; RODRIGUES, J. S.; MOREIRA, V. R.; LEBRON, Y. A. R.; SANTOS, L. V. S.; et al. Occurrence, removal and seasonal variation of pharmaceuticals in Brasilian drinking wáter treatment plants. Environmental Pollution. 2019;250:773-781.

MA, R.; QU, H.; WANG, B.; WANG, F.; YU, G. Widespread monitoring of chiral pharmaceuticals in urban rivers reveals stereospecific occurrence and transformation. Environment International. 2020;138:105657.

MADUREIRA, T. V.; ROCHA, M. J.; CASS, Q. B.; TIRITAN, M. E. Development and optimization of a HPLC-DAD method for the determination of diverse pharmaceuticals in estuarine surface waters. Journal of Chromatographic Science. 2010;48(3):176-82.

MILLER, J. N.; MILLER, J. C. Statistics and Chemometrics for Analytical Chemistry, 6st ed., Pearson: Harlow, 2010.

MONTEIRO, S. C.; BOXALL, A. B. A. Occurrence and fate of human pharmaceuticals in the environment. Reviews of Environmental Contamination and Toxicology. 2010;202:53-154.

OCDE - Organização para a Cooperação e Desenvolvimento Econômico. Health at a Glance; 2013. p. 123-55.

PAIGA, P.; SANTOS, L. H. M. L. M.; DELERUE-MATOS, C. Development of a multi-residue method for the determination of human and veterinary pharmaceuticals and some of their metabolites in aqueous environmental matrices by SPE-UHPLC-MS/MS. Journal of Pharmaceutical and Biomedical Analysis. 2017;135:75-86.

PENG, X.; TAN, J.; TANG, C.; YU, Y.; WANG, Z. Multiresidue determination of fluoroquinolone, sulfonamide,trimethoprim, and chloramphenicol antibiotics in urban watersin China. Environmental Toxicology and Chemistry. 2008;27(1):73-79.

PEREIRA, A. M. P. T.; SILVA, L. J. G.; LINO, C. M.; MEISEL, L. M.; PENA, A. Assessing environmental risk of pharmaceuticals in Portugal: an approach for the selection of the Portuguese monitoring stations in line with directive 2013/39/EU Chemosphere. 2016;144:2507-2515.

PINHO, G. P.; SILVÉRIO, F. O.; NEVES, A. A.; QUEIROZ, M. E. L. R.; STARLING, M. A. V. M. Influência dos constituintes químicos dos extratos de diferentes matrizes na resposta cromatográfica de agrotóxicos. Química Nova. 2010;33(4).

REIS, E. O.; FOUREAUX, A. N. S.; RODRIGUES, J. S.; MOREIRA, V. R.; LEBRON, Y. A. R.; SANTOS, L. V. S.; et al. Occurrence, removal and seasonal variation of pharmaceuticals in Brasilian drinking water treatment plants. Environmental Pollution. 2019;250:773-781.

SANTOS, L. H. M. L. M.; GROS, M.; RODRIGUEZ-MOZAZ, S.; DELERUE-MATOS, C.; PENA, A.; BARCELÓ, D.; et al. Contribution of hospital effluents to the load of pharmaceuticals in urban 
wastewaters: identification of ecologically relevant pharmaceuticals. Science of the Total Environment. 2013; 461-462:302-316.

SCHLÜSENER, M. P.; HARDENBICKER, P.; NILSON, E.; SCHULZ, M.; VIERGUTZ, C.; TERNES, T. A. Occurrence of venlafaxine, other antidepressants and selected metabolites in the Rhine catchment in the face of climate change. Environmental Pollution. 2015;196:247-256.

SIM, W. J.; LEE, J. W.; OH, J. E. Occurrence and fate of pharmaceuticals in wastewater treatment plants and rivers in Korea. Environmental Pollution. 2010;158(5):1938-47.

VERLICCHI, P.; AL AUKIDY, M.; ZAMBELLO, E. Occurrence of pharmaceutical compounds in urban wastewater: removal, mass load and environmental risk after a secondary treatment-a review. The Science of the Total Environment. 2012;429:123-155.

VON SPERLING, M. Princípios do tratamento biológico das águas residuárias: introdução à qualidade das águas e ao tratamento de esgotos. 3st ed. Belo Horizonte: UFMG; 2005.

WILLE, S. M. R.; COOREMAN, S. G.; NEELS, H. M.; LAMBERT, W. E. E. Relevant issues in the monitoring and the toxicology of antidepressants. Critical Reviews in Clinical Laboratory Sciences. 2008;45(1):25-89. 